\title{
Investigating The Influence Of Financial Reward On Lagos State University Staff Turnover Intention
}

\author{
Rasheed Olawale, Azeez, B.Sc, M.Sc \\ Lagos State University, Ojo. Lagos State. Nigeria. \\ Ibrahim Olanrewaju, Lawal, B.Sc, MSc., PhD in view \\ Kwara State University, Malete. Ilorin, Kwara State. Nigeria.
}

doi: 10.19044/esj.2016.v12n10p161 URL:http://dx.doi.org/10.19044/esj.2016.v12n10p161

\begin{abstract}
This study investigated the nature of relationship between turnover intention and financial rewards.Turnover intention can be linked to a situation where motivators are not put in place to get the best out of workers.Simple random sampling techniques was used to select 400 staff (male, $n=250$, female, $n=150$ ) of Lagos State University. A self-administered questionnaire was used to collect data from the participants using Pay Satisfaction Scale (PSS) adapted from the Spector's Job Satisfaction Scale and the Turnover Intention Scale (TIS) from Mobley, Horner, and Hollingsworth (1978).Pearson's Product Moment correlation coefficient was used to analyze the data gotten from the participants. One hypothesis was tested and it was found that there is a significant positive relationship between turnover intention and financial rewards. This study recommends that pay satisfaction of workers should be an uttermost concern for the university management so as to reduce staff turnover intentions.
\end{abstract}

Keywords: Turnover Intention, Financial Rewards, Salaries, Fringe Benefits

\section{Introduction}

Turnover intention can be linked to a situation where motivators are not put in place to get the best out of workers.Problem of the retention of employees' that have skills that are rare and inimitable have been a major obstacle facing organizations in the developing, developed and the less developed countries in the world. It is not a fallacy or a misnomer to assert that financial rewards are necessary to stimulate a worker positively and to get the best out of them. Although, there are many motivators but financial reward takes a front row because it helps an employee settles his/her economic problem. Singh and Loncar (2010), advanced that looking at turnover financially, it can be disastrous to an organization. Employee that 
leaves an organization will make the organization search for new and capable hands which will push forth to the organization; cost of recruitment and training. In line with this, Salleh, Nair, and Harun (2012), posits employee turnover may hinder the productivity and performance level of an organization especially when that employee is in a top level position in the organization.

This means that employee in the managerial level leaving an organization may bring low productivity and performance level. We can say that financial reward is essential to reduce the turnover intention of an employee. That is why, Ismail and Lim (2007)postulates that a company that does not reduce its employee turnover figure will definitely lose competitiveness in the long run.Owing to these injurious consequences, it is pertinent for organization to understand the factors that are contributing to employees' turnover in organizations, because actors affecting employee turnover today have become increasingly complex (Lee, Huang, \& Zhao, 2012). This is why the study focuses on understanding thecurrent level of financial rewards and turnover intention among staff of Lagos State University, Nigeria. Second, the study also sought to investigate the extent to which staff turnover intention is influenced by financial rewards. Finally, ways of creating an organizational climate conducive in retaining academic institution staff are suggested.

\section{Objectives of the Study}

The main drive of this study is to investigate the influence of financial rewards on turnover intention in the Lagos State academic environment. It precisely investigates the level of financial rewards among staff of the institution; assesses how salaries and bonuses affect staff positively; observes reasons of turnover intention among staff in Lagos State University.

\section{Literature Review}

\section{Turnover Intention}

Oluwafemi (2013), noted that turnover intention literature has undergone tremendous evolutionary changes in the past three decades. Various scholars, researchers and academic have defined the construct according to their view and perspective.Saeed, Waseem, Sikander, and Rizwan (2014), opined that turnover is of two types; voluntary turnover and involuntary turnover. Voluntary turnover is initiated by the employee(Veen, 2013). Employees can leave an organization for a variety of reasons, e.g. a better job offer or unsatisfied with the current organization. While involuntary turnover referred to the termination or discharge of an employee by the employer (Shaw, Delery, Jenkins, \& Gupta, 1998). 
Virtually all organizations in the world faces the issue of turnover of employees, some employees leaves the organization willingly while some are fired by their employers. Whichever way the construct is looked from turnover has an adverse effect on the organization.Turnover intention has been conceptualized by Price (2001) as the "individual movement across the membership boundary of an organization". This presupposes that an employee moves away from an organization or separates from the organization.

From the forgoing, we advanced that turnover intention is the intent of an employee to leave an organization in search of a new job. It is important to note that employees' work interdependently in an organization and the turnover of one employee can lead to the less efficiency and effectiveness of other employees (Riley, 2006). That was why Grobler (2005) affirms that minor turnover of employees' in an organization brings about change and innovation.

\section{Financial Rewards}

Rewards is one of the important components to motivate staff for contributing their ultimate performance to generate innovative concepts that leads to better business functionality and further improvise company performance both financial and non-financially (Aktar, Sachu, \& Ali, 2012), and also for organization to gain competitive advantage in this globalizing world. Financial reward according to Nazir, Wang, Akhtar, Shafi\&Nazir, (2015) is sacrosanct to any occupation that we might engage in. In other words most people participate in varied occupation or functional activities because of financial gains. Financial rewards such as pay; has been seen in the literature as one of the essential driving force of an employee (Rynes, Gerhart, \& Minette, 2004).Fapohunda (2012), advanced that pay is an important process in human resources management covering economic rewards in form of wages. Also, Yousaf, Latif, Aslam, and Saddiqui (2014), noted that financial rewards are important for employee motivation in third world countries such as Nigeria.

A financial reward has a positive impact on the performance of an employee; in other words if salary is increased apparently there will be an increase in performance. We can conclude that there is an influence of financial reward on performance. The uninterrupted correlation between financial reward and performance is established on numerous dynamics. On the one hand workers observe satisfactory amount of impartiality between financial rewards and work done by them. On the other hand workers believe if their performance is better they would have good financial rewards. Green (1977) as cited in Fapohunda (2012)upholds that "rewards constitute a necessary intervening variable and this satisfaction is considered as a 
function of performance related reward which implies that performance causes satisfaction". This presupposes that increase in financial reward is as a result of good and satisfactory performances.

Financial reward has been seen to help boost workers performance and help employees' get job satisfaction. It would not be a contradiction to uphold that happy employees' bring about healthy organization. Employees who are satisfied on their job bring joy, happiness, effective communication, peace etc., to their respective organizations. While an unhappy employee will causes conflict, chaos and acrimony in the workplace. The unhappy employee want to sabotage the effort of the organization; which can apparently make the organization not get competitive advantage.

There are various types of financial rewards but for the purpose of this study we will limit ourselves to salary and bonuses.

\section{Salary}

The theoretical basis for money as an effective incentive motivator has been given attention over the years (Mitchell \& Mickel,1999) as cited in (Peterson \& Luthans, 2006). Salary has been seen as the secured amount being paid by an employer for a job completed by an employee. Heathfield (2012) as noted by Mustapha (2013), argued that salary is a fixed amount of money or compensation paid to an employee by an employer in exchange for a productive work performed. We would appreciate the fact that salary and employee motivation are mutual interpenetrating and reinforcing. (Mustapha (2013)), noted that remuneration system plays an important role in determining an employee's level of job satisfaction. The limitless needs of families in this developing part of the world with higher living costs might push employees to seeking higher income that can assure their future and life satisfaction. If individuals believe they are not compensated well, a state of emotional dissatisfaction will develop. This emotional disagreement will accrue over time and make the employee want to leave the organization in search of greener pasture.

\section{Fringe Benefits}

Employee benefits include various types of non-wage compensation (allowances) provided to employees in addition to their normal wages or salaries. ${ }^{[1]}$ In instances where an employee exchanges (cash) wages for some other form of benefit is generally referred to as a 'salary packaging' or 'salary exchange' arrangement. In most organization, most kinds of employee benefits are taxable to at least some degree. Examples of these benefits include: housing (employer-provided or employer-paid), group insurance (health, dental, life etc.), disability income protection, retirement benefits, daycare, tuition reimbursement, sick leave, vacation (paid and non-paid), 
social security, profit sharing, funding of education, and other specialized benefits. The purpose of employee benefits is to increase the economic security of staff members, and in doing so, improve worker retention across the organization \{Abernethy, 2005). As such, it is one component of reward management.

\section{Empirical Literature Review}

One fundamental question in organizational behavior literature that has preoccupied scholars and researchers is why do people get dissatisfied and leave their organization.

If any person has to come up with the question that is there any need for turnover? The answer to this type of question of-course should be simplethe basic survival of every organization is it public or private limited before, today and in the foreseeable future lies in how well its work force is satisfied and committed to meet the objectives of the organization. This explains why the human resource department in today's organization is becoming a focus of the company's core functions. We think that satisfied and committed employees are needed in this rapidly changing business world where conflict is the issue confronting most managers. Most organizations now consider their human resources as their most valuable assets (a strategic or competitive advantage).

Therefore, in order to effectively and efficiently utilize this strategic asset, satisfaction and commitment of the employees' are required. They should be committed so their turnover intent can be jettisoned.

Findings indicated that reward contingencies moderate the performance-turnover relationship in the sense that higher performers reported more turnover intentions when rewards were not perceived as contingent on performance (Sturman \& Trevor, 2001). Also, Trevor, Gerhart, and Boudreau (1997), explained this phenomenon by suggesting that highperformer turnover is greater under the condition of low reward contingency because the desire to change jobs should increase as reward inequity increases. Therefore, when a weak pay-for-performance link exists, turnover of the best people may occur because they perceive that their high performance will not be sufficiently rewarded.

\section{Statement of Hypothesis}

The study tested the null hypothesis below.

$\mathrm{H}_{\mathrm{o}}$ : There is no significant influence of financial rewards on turnover intention. 


\section{Methodology}

\section{Data collection and analysis}

The sample for this study consisted of academic and non-academic employees working at Lagos State University. A self-administered questionnaire was used to determine the influence of financial rewards on turnover intention. A pilot survey instrument was distributed to 50 academic and non-academic staff. The result of the pilot study allowed the researchers to reword some of the questions for better understanding. A total number of 400 questionnaires were administered on the staff. Each instrument was administered personally to each participant and collected immediately and sometimes the following day for proper documentation. A total of 320 questionnaires were correctly filled and returned out of the 400 questionnaires distributed to the participants, yielding a response rate of 80 percent.

First, descriptive statistics were used to identify the respondents' demographic characteristics. Second, a validity and reliability test was done to obtain the Cronbach alpha and the Kaiser-Meyer-Olkin measure of sampling adequacy is used to obtain the validity indices.The hypothesis was done through the use of Pearson product Moment correlation coefficients. Correlation analysis is the study of the relationship between two variables. It is used to measure the strength of association between two variables. The coefficient of correlation describes the strength of the relationship between two variables ' $r$ '. ' $r$ ' refers to the Pearson product moment correlation coefficient. An ' $r$ ' -1.0 0r +1.0 indicates correlation while 0 indicates no relationship.

\section{Measurement}

\section{Financial rewards}

Financial rewards was measured by the adaptation of the Spector (1994) job satisfaction scale using questions 1, 10, 13, 19 and 27 with (Cronbach Alpha $=0.72$ ) and it used a Likert scale. Participants were asked to indicate their level of agreement with each statement regarding their financial reward orientation. Financial Rewards scale used a Likert scale.

\section{Turnover intention}

Turnover intention was measured with three items (Cronbach Alpha = 0.83) from Mobley, Horner, and Hollingsworth (1978). To determine LASU staff intention to leave their jobs, respondents were asked to indicate their level of agreement with each item using a five-point scale. Sample item is "I often think about quitting my present job". 


\section{Demographic characteristics}

The demographic factors of gender, age, and staff classification were measured.

\section{Results}

Table 1 below shows that $65 \%$ of the respondents are male while the remaining 35\% makes up the female gender. This implies that we have more males in the organization than female.

Table 1 gender

\begin{tabular}{|c|c|c|c|c|}
\hline & & Frequency & Percent & Valid Percent \\
\hline \multirow{3}{*}{ Valid } & MALE & 208 & 65.0 & 65.0 \\
\hline & FEMALE & 112 & 35.0 & 35.0 \\
\hline & Total & 320 & 100.0 & 100.0 \\
\hline
\end{tabular}

Table 2 shows that $3.4 \%$ of the respondents are school certificate holder, while $10.3 \%$ of the respondents have national diploma qualification. Also, $40.3 \%$ are holders of HND/BSc certificate while $14.7 \%$ are holders of M.Sc certificate. $31.3 \%$ of the respondents are holders of a $\mathrm{PhD}$ degree.

Table 2 educational qualification

\begin{tabular}{|cc|c|c|c|}
\hline & & Frequency & Percent & $\begin{array}{c}\text { Valid } \\
\text { Percent }\end{array}$ \\
\hline \multirow{4}{*}{ SCHOOL CERT. } & 11 & 3.4 & 3.4 \\
NATid & DIPLOMA & 33 & 10.3 & 10.3 \\
& HND/BSc & 129 & 40.3 & 40.3 \\
& MSc & 47 & 14.7 & 14.7 \\
& PhD & 100 & 31.3 & 31.3 \\
& Total & 320 & 100.0 & 100.0 \\
\hline
\end{tabular}

Table 3 shows that $4.1 \%$ of the respondents have 1-5years experience while $38.1 \%$ have $6-10$ years' experience. Furthermore, $32.8 \%$ has $11-15$ years' experience, while $4.7 \%$ holds between $21-25$ years of experience. $2.8 \%$ of the respondents have more than 25years of experience.

Table 3 work experience

\begin{tabular}{|c|c|c|c|c|}
\hline & Frequency & Percent & Valid Percent \\
\hline \multirow{7}{*}{ Valid } & 1-5 YEARS & 13 & 4.1 & 4.1 \\
\hline & 6-10 YEARS & 122 & 38.1 & 38.1 \\
\hline & 11-15 YEARS & 105 & 32.8 & 32.8 \\
\hline & 16-20 YEARS & 56 & 17.5 & 17.5 \\
\hline & 21-25 YEARS & 15 & 4.7 & 4.7 \\
\hline & ABOVE 25 & 9 & 2.8 & 2.8 \\
\hline & Total & 320 & 100.0 & 100.0 \\
\hline
\end{tabular}


Table 4 shows that $58 \%$ of the respondents are academic staff while $42 \%$ are non-academic staff

Table 4 staff classification

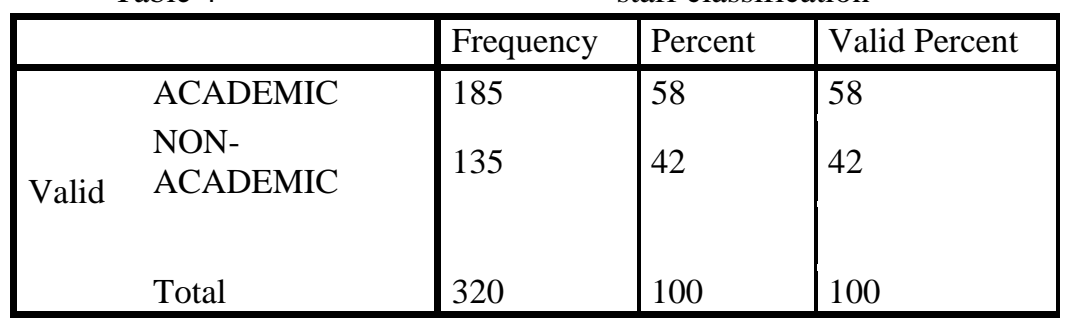

\section{Hypothesis testing}

$\mathbf{H}_{\mathbf{0}}$ : There is no significant influence of financial rewards on turnover intention.

Correlations

\begin{tabular}{|cc|c|c|}
\hline & & TURNOVER & FINANCIAL \\
INTENTION & REWARD \\
\hline TURNOVER & Pearson Correlation & 1 & .840 \\
INTENTION & Sig. (2-tailed) & & .001 \\
& $\mathrm{~N}$ & 320 & 320 \\
FINANCIAL & Pearson Correlation & .840 & 1 \\
REWARD & Sig. (2-tailed) & .001 & \\
& $\mathrm{~N}$ & 320 & 320 \\
\hline
\end{tabular}

SPSS Output: 2015

The aboveresult shows that there is a relationship between turnover intention and financial rewards. This is so because the p-value $(0.001)$ is lesser than (0.005) level of significance. This implies that turnover intention has a significant andpositive relationship with financial rewards. Therefore, the null hypothesis is rejected and the alternate hypothesis is accepted. The implication of this is that the lower turnover intention is the higher financial reward is and vice versa.This findings is supported by the study of Fapohunda (2012)who affirms that paying of good wages is important in an organization to enhance productivity and reduce turnover intention of workers.Giving adequate financial rewards can help retain quality staff that are rare and help increase employees’ commitment.

\section{Conclusion}

Having carefully analyzed the research findings, the following suggestions are recommended to the university owner and policy makers which will help reduceturnover intention of workers;

The recommendations are as follows: 
1. That to remain competitive in the academic industry, there is need for workers commitment and satisfaction via good financial packages.

2. Bonuses such as payment for leave, $\mathrm{PhD}$ sponsorship should be put in place so as to reduce turnover of labour to organization that has the packages in place.

3. Pay satisfaction of workers should be an uttermost concern for the university management so as to reduce turnover.

In light of the present challenges that has engulfed many organizations in the public and private sector of the economy; there exists a grave concern regarding how to maximize their profit using limited cost. In maximizing their profit, the satisfaction of their employees' must not be taking with levity. Reduction of the employees' turnover intention must be reduced to the barest minimum with good financial reward in place.

\section{References:}

Abernethy, M.A., Horne, M.H., Lillis, A.M., Malina, M.A. and Selto, F.H., (2005), 'A multi-method approach to building causal performance maps from expert knowledge.

Aktar, S., Sachu, M. K., \& Ali, M. E. (2012). The impact of rewards on employee performance in commercial banks of Bangladesh: an empirical study. IOSR Journal of Business and Management, 6(2), 9-15.

Fapohunda, T. M. (2012). Pay disparity and pay satisfaction in public and private universities in Nigeria. European Scientific Journal, 8(28), 120-135.

Grobler, P. A. (2005). Human resource management in South Africa: Cengage Learning EMEA.

Ismail, M. N., \& Lim, S. (2007). Effects of attitudes, job characteristics and external market on employee turnover: A study of Malaysian information technology workers. Unpublished Doctoral Thesis. University of Malaya. Malaysia.

Lee, C.-C., Huang, S.-H., \& Zhao, C.-Y. (2012). A study on factors affecting turnover intention of hotel empolyees. Asian Economic and Financial Review, 2(7), 866-875.

Mobley, W. H., Horner, S. O., \& Hollingsworth, A. T. (1978). An evaluation of precursors of hospital employee turnover. Journal of Applied psychology, 63(4), 408-414.

Mustapha, N. (2013). The influence of financial reward on job satisfaction among academic staffs at public universities in kelantan, malaysia. International Journal of Business and Social Science, 4(3), 244-248.

Nazir, S., Wang, Q., Akhtar, M. N., Shafi, A., \& Nazir, N. (2015). Financial rewards climate and its impact on employee attitudes towards job satisfaction in the retail organizations. European Scientific Journal, 11(1), 351-364. 
Oluwafemi, O. (2013). Predictors of turnover intention among employees in Nigeria’s oil industry. Organizations and Markets in Emerging Economies, 1(2), 42-63.

Peterson, S. J., \& Luthans, F. (2006). The impact of financial and nonfinancial incentives on business-unit outcomes over time. Journal of applied Psychology, 91(1), 156-165.

Price, J. L. (2001). Reflections on the determinants of voluntary turnover. International Journal of Manpower, 22(7), 600-624.

Riley, D. (2006). Turnover intentions: The mediation effects of job satisfaction, affective commitment and continuance commitment. (Master), The University of Waikato.

Rynes, S. L., Gerhart, B., \& Minette, K. A. (2004). The importance of pay in employee motivation: Discrepancies between what people say and what they do. Human resource management, 43(4), 381-394.

Saeed, I., Waseem, M., Sikander, S., \& Rizwan, M. (2014). The relationship of Turnover intention with job satisfaction, job performance, Leader member exchange, Emotional intelligence and organizational commitment. International Journal of Learning and Development, 4(2), Pages 242-256.

Salleh, R., Nair, M. S., \& Harun, H. (2012). Job Satisfaction, Organizational Commitment, and Turnover Intention: A Case Study on Employees of a Retail Company in Malaysia. World Academy of Science, Engineering and Technology, 6(12), 316-323.

Shaw, J. D., Delery, J. E., Jenkins, G. D., \& Gupta, N. (1998). An organization-level analysis of voluntary and involuntary turnover. Academy of management journal, 41(5), 511-525.

Singh, P., \& Loncar, N. (2010). Pay satisfaction, job satisfaction and turnover intent. Relations industrielles/industrial relations, 65(3), 470-490.

Spector, P. E. (1994). Using self-report questionnaires in OB research: A comment on the use of a controversial method. Journal of Organizational Behavior, 15(5), 385-392.

Sturman, M. C., \& Trevor, C. O. (2001). The implications of linking the dynamic performance and turnover literatures. Journal of Applied Psychology, 86(4), 684-696.

Trevor, C. O., Gerhart, B., \& Boudreau, J. W. (1997). Voluntary turnover and job performance: Curvilinearity and the moderating influences of salary growth and promotions. Journal of applied psychology, 82(1), 44-61.

Veen, N. (2013). The effect of mergers and acquisitions on voluntary turnover. Unpublished Thesis. Business administration. University of Twente. Enschede.

Yousaf, S., Latif, M., Aslam, S., \& Saddiqui, A. (2014). Impact of Financial and non Financial Rewards on Employee Motivation. Middle-East Journal of Scientific Research, 21(10), 1776-1786. 